\title{
STUDIES OF THE NESTING ACTIVITIES OF' LATIMER'S VIREO (VIREO LATIMERI BAIRD)
}

\author{
By Nina G. SPAULding
}

The observations included in this paper were made at Algarrobo, which is situated about half way between Vega Baja and Manatí on the north coast of Puerto Rico. Here, a sandy, brush-covered coastal plain which includes Laguna Tortuguera and varies in width from about three to five miles, is abruptly terminated on the south by a series of steep, rugged, limestone hills. East and west the plain extends unbroken for miles.

This study was made on a five-hundred acre finca extending from the shore of Laguna Tortuguera, across the coastal plain, back into the first outcropping of limestone hills. Only a small percentage of this acreage was under cultivation. The remainder was overgrown with a low growth of scrub and brush. In sections, especially over certain parts of the coastal plain and in poorly kept pasture lands the growth was sparse. Other sections, including the hills were so densely wooded and tangled with vines that a path had to be eut in order to penetrate them. There were many small trails throughout the finca. It was the exact type of couritry favored by the species under consideration. A particularly attractive locality was a brushy pasture through which meandered a sluggish brook, bordered by a low growth of shrubs and trees.

The study in hand covers a period of three seasons, the first in 1927, from March 2 to June 20; the second, in 1930, from April 1 to May 27; the third in 1931, from January 27 to June 20.

Song.-The song of this species is exceedingly sprightly and vivacious. It usually consists of four syllables two of which are strongly accented. The accent most commonly falls on either the first and last or second and last syllables, as moó-cha-che-píb; pa wé pa chú. Sometimes only one accent occurs, as pa-chibby-chú. Syllables are occasionally increased in number, as cha-icha-reécha-roók, and sometimes decreased, as, wé-pa-yoú. One couplet may be sung at intervals of from one to three seconds and for a period of several minutes and then change to a different couplet and continue in the same manner. On February 10, for a period of two hours, a bird, 
presumably a male, sang on an average of every 4 minutes and 16 seconds. Song activity occurs with the greatest frequency and vivacity from the time the male first acquires his territory, through courtship to about the middle of the nest construction period. From that time frequency and vivacity gradually wane, but it is the custom of the male to sing throughout the breeding cycle. The female sings also, but her singing is restricted to the courting season and in some individuals continues while nest building is in progress. One supposed female was noted constructing a nest (with her mate), who never uttered a note. When the female is in song, singing occurs responsively between the pair. At times responses follow so rapidly that at the climax, both birds are singing at once a most lively medley of all the varying couplets in their repertoire. Such an exhibition sometimes lasts unbroken for 20 minutes. One such was noted as early as Fiebruary 26. This was during courtship. Another courtship display, sex undetermined, was the utterance of a rattle-like note, chur-chur-chur-r-r-r given loudly and sprightly with increasing rapidity, in response to a couplet sung by the mate. This species also has a love warble. It occurs so rarely that one is fortunate to hear it. One such exhibition consisted of one syllable uttered rapidly on the same pitch, with increasing rapidity, and finally terminating in a deliciously sweet-toned but almost inaudible series of liquid notes.

Responsive singing not only occurs between the two sexes, but also between two males (supposedly) in adjoining territories. When a mate enters the territory of another bird a lively duet ensues, and the intruding bird soon departs. One such event was noted when a pair were feeding near a nest they were building. One of the mated pair took no part in the singing.

Call Notes.-These were of three types: a grating, hoarse, cat-like mew; watchman's rattle-like churr-r-r-r-rrr, sometimes increasing in rapidity and accent, then diminishing and descending at the end, used at times as a scold note and at times in courtship, as has been stated, and tup tup often used as a conversational note by a pair when busy gleaning insects or nesting material together.

Territory.-This species has a well-defined territory, most easily determined preceding the time that the male acquires a mate. His voice is then heard daily within certain limited confines, beyond which he never seems to go. The nest is most frequently built on one of 
its borders, and the rest is used as a feeding ground. In one instance the nest was placed in a line of trees and brush, beside which was a foot trail. Beyond that lay the feeding ground. It was quite densely covered with icaco (Chrysobalamus icaco L.). Territories are acquired at an early date. On my earliest arrival at the finca (Jan. 27), a solitary male whose activities were limited to one particular locality was noted. Day after day all day long his voice could be heard as he assiduously searched for insects within this limited area. He had chosen brushy pasture land, through which ran.a sluggish, brush-bordered brook. Another male which had chosen for his territory a jungle-tangled hillside had a mate upon my first record of him (Feb. 3).

Nest.-The nest is cup-shaped and pendant. It is supported between two forked or parallel twigs, and is situated $3 \frac{1}{2}$ to 8 feet above the ground. It almost invariably overhangs an open space in the midst of a thicket, or else is found in a shrub or tree in a wind-break, bordering an open field, or in a border line of brush on the edge of a woods.

It is composed of 3 layers, the outer or camouflage, the foundation layer and the lining. The eamouflage layer consists of bits of green moss, tan colored plant known and white spider egg sacs. This layer is unevenly distributed. Stems of Spanish or Florida moss (Tillandsia usneoides L) with the outside removed by decay, compose the foundation layer. The lining is a scanty layer of wiry, dried grass. Cobweb is employed to seal the nesting material over the two supporting twigs. We are indebted to Dr. Nathaniel L. Britton for identification of the Tillandsia stems, which have the appearance of black horsehair. When completed, the nest is a dainty, transparent affair and is so fragile that the incubating bird can be partially seen through the nest wall. Dimensions in inches average:

Outside

Length $21 / 2$

Width 2

Depth $21 / 4$
Inside

$23 \%$

$11 / 2$

$21 / 8$

The height of the nest-building season is in the early part of May. One nest observed was begun on the second of that month. Many completed nests are found by the 15th. My latest record for the beginning of nest building occurred on May 16. March 20 is my earliest record. 
In the one case of entire nest construction which I had an opportunity to observe, the pair spent 10 days to the laying of the first egg, though the nest was practically finished in 6 days. Both birds shared in its construction until the afternoon of the 5th day, when the female, apparently, did all the work. The male continued to sing but no response came from the busy female. However, the male was a close attendant to his mate, hovered in the vicinity of the nest while the female was away searching for nesting material. Upon her arrival at the nest, he would sing in the bushes close by.

At the beginning of the nest, Tillandsia stems were dropped loosely over the two twigs from which the birds had chosen to suspend it. Later in the day, spider egg saes were dropped into the dangling stems. Only three eaught in its meshes. About 4 P. M., a loose combination of the pendant stems was effected, when twice one of the pair slipped between the supporting twigs, and by kicking and squirming matted and interweaved them to form the base of the nest.

During the second morning, the material brought consisted of spider egg saes and two deposits of Tillandsia. At 12 M., the first load of plant down was brought. Tillandsia stems still dangled loosely.

By the 5th day the nest had been wholly closed beneath. Moss had been added and kicked through the matted Tillandsia stems to the outside. With the exception of one Tillandsia stem, moss continued to be the only material added that morning. In the afternoon, 4 loads of wiry, dried grass, 1 of Tillandsia, 2 of cobweb and 2 of plant down were deposited in the order given. The plant down was nestled through to the outside where it appeared with the green moss and spider egg saes in the outer layer. Dried grass was the only material added on the 6 th day. In the morning 10 loads were brought, averaging one every $171 / 2$ minutes. In the afternoon only 3 visits were paid to the nest, averaging one every 48 minutes. No song was uttered by the worker, indicating it to be the female. Singing by the male had markedly decreased, averaging one period every 18 minutes. Once, one of the pair uttered the love warble, sex unknown, but presumably, the male.

No nesting material was added after the 6 th day to my knowledge. Stealthiness of movements increased. Singing by the female had ceased entirely by the 10th day, when the first and only egg was laid. The pair deserted the nest on the 12th day. 
DATA REGARDING NESTS OBSERVED

\begin{tabular}{|c|c|c|c|c|c|c|c|}
\hline 岁 & 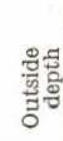 & 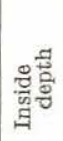 & 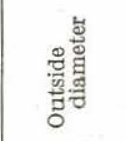 & 莺离 & 胥, & Tres & 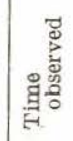 \\
\hline $\begin{array}{l}1 . \\
2 .\end{array}$ & $\begin{array}{l}21 /{ }^{\prime \prime} \\
13 / \mathrm{s}^{\prime \prime}\end{array}$ & $\begin{array}{l}211 / 2 \prime \prime \\
12^{\prime \prime}\end{array}$ & $\begin{array}{l}23 / 4^{\prime \prime} \times 21 / 2^{\prime \prime} \\
234^{\prime \prime} \times 22^{\prime \prime}\end{array}$ & $\begin{array}{l}21 / 2^{\prime \prime} \times 2 \quad \prime \prime \\
21 / 2^{\prime \prime} \times 11^{\prime \prime}\end{array}$ & $\begin{array}{l}8 \text { ft. } \\
4 \text { ft. } 8 \prime \prime\end{array}$ & $\begin{array}{l}\text { Guamá (Inja laurina. Willd) ........ } \\
\text { Rama Menuda (Myrcia splendens Sw.) }\end{array}$ & ${ }_{11 / 2}^{24 h}$ \\
\hline $\begin{array}{l}3 . . \\
4 .\end{array}$ & & & $\begin{array}{l}21,2^{\prime \prime} \times 2 \quad \prime \prime \\
22_{2 \prime \prime}^{\prime \prime} \times 2\end{array}$ & & 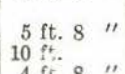 & $\begin{array}{l}\text { DC } \\
\text { Pomarrosa (Eugenia jambos } L) \text { Br....... } \\
\text { (Taonobo Sivhlii. Kr \& U Urb.) Britton... }\end{array}$ & $\begin{array}{ll}5 & \mathrm{~h} \\
0 & \mathrm{~h}\end{array}$ \\
\hline $\begin{array}{l}5 . \\
6 . \\
7 .\end{array}$ & $\begin{array}{l}2 \\
2\end{array}$ & $13 / 4{ }^{\prime \prime \prime}$ & $\begin{array}{ll}21 / 2 \prime \prime & \times 2 \\
23 / 4 & \prime \prime\end{array}$ & $21 / 2^{\prime \prime} \times 11 / 2^{\prime \prime}$ & $\begin{array}{l}4 \mathrm{ft} .8 \\
3 \mathrm{ft} .7\end{array}$ & $\begin{array}{l}\text { (Tao zobo Sthlii. } K r \& \text { Urb.) Britton... } \\
\text { (Taonobo Stahlii. Kr \& Urb.) Britton... }\end{array}$ & $21 / 4 \mathrm{~h}$ \\
\hline & & & & & & 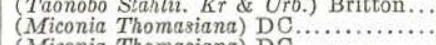 & $\begin{array}{ll}0 & \mathrm{~h} \\
1 & \mathrm{~h}\end{array}$ \\
\hline 10. & & & & & 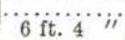 & $\begin{array}{l}\text { (Miconia Thomasiana) DC. } \ldots 7 \\
\text { Pomarrosa (Eugenia jambos } L \text { ) } \mathrm{Br} \text {. }\end{array}$ & $\begin{array}{l}1 / 2 \mathrm{~h} \\
61 / 2 \mathrm{~h}\end{array}$ \\
\hline $\begin{array}{l}11 . . \\
12 .\end{array}$ & $\begin{array}{l}2 y^{\prime \prime \prime} \\
234^{\prime \prime}\end{array}$ & $\begin{array}{l}214^{\prime \prime} \\
21 / 2^{\prime \prime}\end{array}$ & $\begin{array}{l}212^{\prime \prime} \times 11^{\prime \prime} \\
212^{\prime \prime} \times 21 / 4^{\prime \prime}\end{array}$ & $21 / s^{\prime \prime} \times 12 / 8^{\prime \prime}$ & & 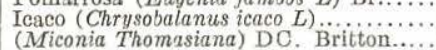 & $10 \mathrm{~h}$ \\
\hline $\begin{array}{l}13 . . \\
14 . .\end{array}$ & $23 / 4$ & $23{ }^{2} i{ }^{i}$ & $\begin{array}{l}21,2^{\prime \prime \prime} \times 22^{3 / 8} s^{\prime \prime} \\
212^{\prime \prime} \times 2^{3 / 8^{\prime \prime}}\end{array}$ & & $5 \mathrm{ft} .912^{i \prime}$ & $\begin{array}{l}\text { Palo de María (Calophyllum antillanum) } \\
\text { Roble Blanco (Tabebuia pallida) Miers. }\end{array}$ & $\begin{array}{l}32 / 3 \mathrm{~h} \\
291 / 3 \mathrm{~h}\end{array}$ \\
\hline $15 .$. & & & & & & $\begin{array}{l}\text { Aceituna Blanca (Symplocos martinicen- } \\
\text { sis) Jaeq. }\end{array}$ & \\
\hline Av. & $21 / 4 "$ & $21 / 8^{\prime \prime}$ & $2 / 2^{\prime \prime} \times 2 \quad "$ & $23 / 8^{\prime \prime} \times 11 / 2^{\prime \prime}$ & & & \\
\hline
\end{tabular}

Eggs.-In life, the eggs are suffused with a roseate hue and are spotted with minute dots of reddish brown. A variation occurs in the size and number of these spots from a very sparse sprinkling to a considerable number. In most cases a wreath of more or less coalesced spots occurs around the larger end. In some instances these spots are a dark seal brown, including a few of pale lavender. The wreath is almost wholly absent when dots over the entire egg are sparse.

In one nest, two eggs that were laid before desertion, measured exactly alike: $20 \mathrm{~mm} \times 13.2 \mathrm{~mm}$. In another similar case, the two eggs measured: $19.5 \mathrm{~mm} \times 14 \mathrm{~mm}$. In still another instance, one egg, each in two different nests (one found on May 10 and the other on June 18 measured $3 / 4$ inch $\times 9 / 16$ inch. The height of the season for egg-laying is from the 10th of May to the 14th of June. The usual number in a clutch is 3 , though one nest found in the process of incubation contained only 2 eggs. Earliest record of eggs laid: April 8 and 9. Latest: June 18.

Incubation.-A nest located on the 9th of June, 1930, offered the only opportunity for protracted observations on the incubating habits of this species. There were 3 eggs, which proved to be within 5 days of hatching. Incubation was shared by both sexes, but unequally, as one of the pair, which did not sing (supposed to be the female), averaged almost twice as much time on the nest as the singer (supposed to be the male). 
The male sang when not on duty at the nest, but his voice was less vibrant and more casual than during the courting and nest-constructing periods, and was heard at rarer intervals. For these reasons and for the fact that no singing occurred when the male was incubating, it was difficult to locate nests after the beginning of this period. When he left the nest, it was his custom to sing at once from a near-by twig. There were a few exceptions when he omitted his song in the immediate environs of the nest, but instead, flew in silence across the foot-trail that separated the nesting tree locality from his feeding territory. His time was divided between these two sections. He seemed to like to hover in the vicinity of his nest and spent his time flitting from bush to bush, searching for insects, occasionally singing and sometimes preening.

Since the female did not sing when freed from incubating duties, it was not possible to follow her movements. She was never seen near the nest; in fact, she kept herself completely invisible.

The habits of the pair when covering the eggs, varied. The female almost invariably faced the fork in the branch from which the nest was suspended, while the male assumed a position at right angles to his mate, with bill propped against one of the supporting nest twigs and his tail against the other. The female was more alert and nervous. She moved her head frequently and sometimes completely changed her position. His movements were less frequent. At times when the male sang on a twig close to the nest, the female would become very alert, reach up her head and peer between the leaves as if to see him. Her behavior at such a time indicated his intentions. If he were ready to relieve her, she would look in all directions to see if it were safe for her to leave the nest, and then creep to the rim and drop out of sight. If he failed to approach, she would quietly settle back in the nest. If any other species of bird invaded her immediate vicinity, she was startled. The flapping wings of a Mocking Bird, and the sharp tink of a Bryant's Grassquit in the shrubbery close by would cause her to raise her head instantly and look all about.

The method of approach and departure from the nest was quite similar on the part of both birds. The approaching bird customarily alighted on the rim of the nest, or on a twig just above it. Usually the departure was slow and cautious up to the final dash, but there were exceptions when the exchange was made swiftly.

I did not see the male turn the eggs. In the morning on the day before the eggs hatched the female turned them at 11.50, 12, 12.09, 
12.13, and 12.20 ; in the afternoon, at 5.12, 5.15, 5.34, 5.40, 6.05, and 6.13. At 5.50 she appeared to be turning the eggs, but when she raised her head she seemed to be eating something. I concluded she was cleaning the nest. At 6.26 , this act was repeated. When turning the eggs, she sometimes accomplished it by tucking her head under her breast, and sometimes by standing and backing up against the side of the nest, then reaching down and moving the eggs with her bill. The nest wall was so thin that the bird was visible through it as she worked inside. Frequently she snuggled and cuddled as she settled over the eggs. Observations were made on this day from 10.40 A. M. to 1.06 P. M. and from 3 to 6.48 P. M. That night, before leaving, I flushed the incubating bird to see if the eggs had hatched. The bird permitted me to lower the branch before making her escape and offered no resistance.

On the day preceding the hatching of the eggs a more cautious behavior was noted on the part of both birds. For the first time they appeared conscious of my presence. This was seen by the manner of approach to the nest. They would come creeping along a twig behind the leaves to the nest and pause. The setting bird would fly or drop down out of sight, and the other would instantly slip inside the nest. I made observations from 9.53 to 12.18 that morning. Eggs were turned but once, and that by the female at 10.02. While the female incubated for 86 minutes the male spent 57 minutes near the nest and only 29 minutes across the trail.

The length of the incubating period remains undetermined. The height of the season occurs from about the 10th of May to the middle of June. Earliest record of an incubating pair: May 12; latest: June 9. Incubation was shared by both sexes, but unequally, as the female covered the eggs nearly twice as long as the male.

Rearing of Young.-The report which follows was obtained from observations of two nests, one of which was that of the incubating birds just described. The 3 eggs were found hatched on June 14 . Observations were continued for three days. In the other, 2 eggs hatched on May 23, and the third on the 24th.

The height of the season occurs from about the 20th of May to the latter part of June.

Both parents shared in the parental duties of brooding and feeding, with the male feeding about four times as often as the female, and the female brooding about twice as much as the male. The young were closely brooded during the four days of observation, the exchange on the nest being effected at once by the pair. When 
the young were left uncovered it was for periods of 5 to 8 minutes, and for this time, only once or twice during a day, for the first two days; on the third day with respect to one nest, five such occasions ocurred, with the longest period lasting 15 minutes.

Unless the female was ready to leave the nest on the arrival of the male with insects, he deposited them in her bill and she in turn mashed and fed them to the young. If she were ready to leave, she would usually fly and he would feed the young himself and remain to brood. Occasionally, the female would take a part of his load to eat, herself, before leaving the nest. Sometimes she would eat the whole load and continue brooding. The female never feeds her load of insects to the brooding male, but always directly to the young. When she arrives he departs. At times, on the approach of the male to the nest, the female repeatedly opens her bill wide and shuts it until he deposits the load in her mouth. Once the male was noted conducting himself in like manner, but she did not offer him any of her load and he flew. Both birds frequently uttered a metallic, tsup tsup, upon approach to the nest, evidently as a warning to the brooding bird to vacate. Insects were often mashed by both the male and female before they were given to the young. At times, after a deposit had been made in the gaping mouth of one of the young, it was withdrawn by the parent, mashed and redeposited. In one instance this was repeated 12 times before it was swallowed. On one occasion, when it was almost dusk, the male came with his last load for the day. It consisted of a larva that hung dangling from his bill, and was so big that the whole family had a meal from it. The female took it and her head disappeared into the nest. When she raised it, some of the worm was still visible in her bill. She held it out to him. He picked off a piece and ate it, and she ate the rest.

On more than one occasion the male arrived at the nest empty billed. He alighted on the twig immediately above it, and looked at his mate in the nest below him, then reached his head down toward her and eyed her slowly with one eye and then the other, with a very solicitous expression. She ignored his presence. He continued to look her up and down from head to tail and back again, but with no response. He then reached down until his bill almost touched hers. She still paid no attention. Presently, he pecked her bill three or four times. This produced no effect. He then hopped to the next twig above, looked back into the nest, erept along the twig and dropped downward. In 2 minutes he returned with an insect, 
but the female did not let him brood until 19 minutes later. On another similar occasion when he touched her bill with his he poked it gently as if nudging her to make her fly and let him brood. She snapped her bill wide open and glared at him. He flew at once. Still another time he alighted on the twig just below the nest and reached his head up close to his mate's so their bills almost touched. They remained thus for 5 . minutes.

Feedings averaged every $91 / 2$ minutes during the whole time observed at the nest which hatched on June 14.

Both birds attended to the cleaning of the nest. The excrement pellets were eaten.

These vireos are fearless in defense of their young. In the case of the May nest it will be recalled that two young and one unhatched egg were found in it, on the 23rd. On that day the brooding bird let me set up the eamera within 2 feet of the nest. When I put my finger almost over him, he pecked at it. Not until I broke off a leaf above him, did he fly. He dashed back at once upon cessation of the disturbance. After all the eggs are hatched the behavior becomes fiercer and bolder. Upon approach to the nest to examine the young the brooding bird alighted on a near-by twig, spread his wings wide, fluttered and uttered his loud, shrieking, grating cat-like drawl, then flew at my face again and again, even daring to strike with his bill. He returned to the nest at once upon my departure. On the second day when the nest had been vacated by the parents for a few minutes, upon may approach to it, both of the pair instantly appeared in defense of the young, one flying at my head and the other bravely alighting in a bush at my feet. Upon my withdrawal, both continued their search for insects close by.

During the hottest part of the day the brooding bird would rise and stand, as if to cool the young. On one such occasion the bird remained thus for 3 minutes.

The young were naked and blind upon hatching. The general color was light reddish pink; the bill was creamy white; top of head, pale flesh color; back, reddish pink; wings the same, except for dark gray along the upper edge; chest reddish pink; belly dark gray; legs pinkish or flesh color. Wing quills began pricking through on the second day.

The young made little peeping sounds, but so faint that they were only audible when one's ear was close to the bottom of the nest. 
A summary of observations on nest activities of the parents whose young hatched on June 14, follows:

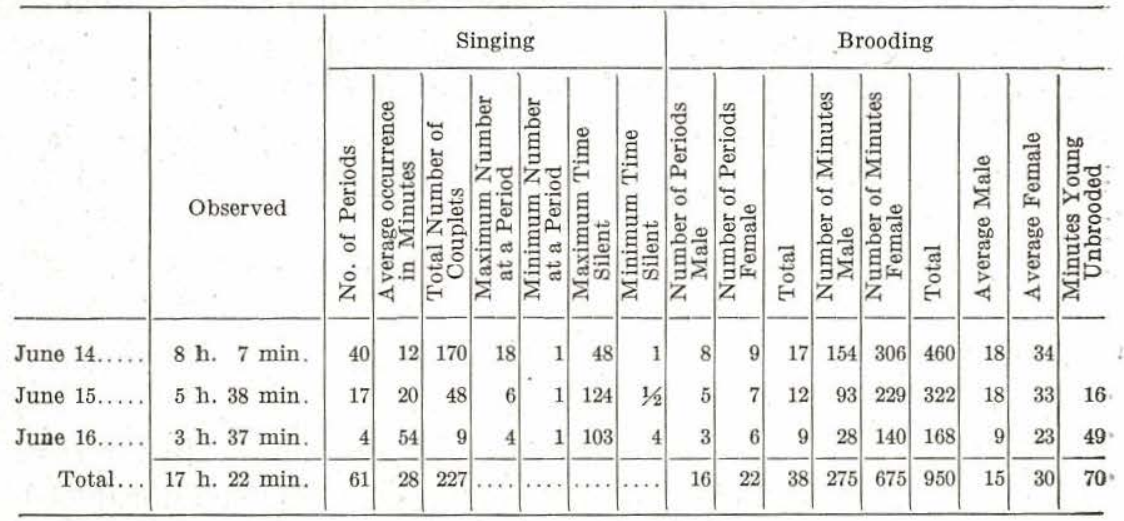

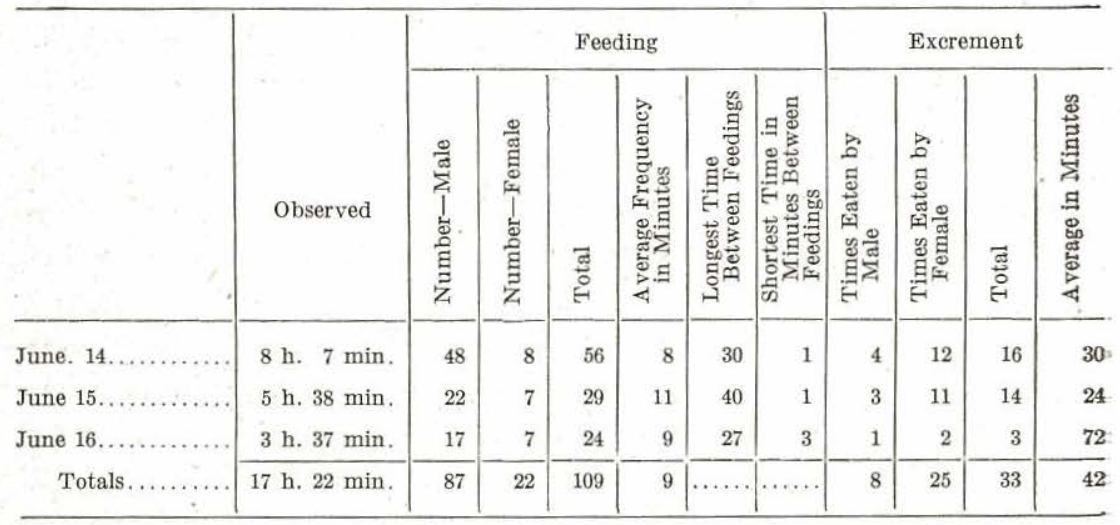

The low average rate of cleaning the nest on the 16th may be due to the fact that on that date observations were not made until late in the afternoon and for a shorter time than on the previous days.

Behavior of Male upon Destruction of Mate and Young.-Unfortunately, the female and young in this nest (June 14) were destroyed between 7 P. M., on the 16 th and 9.30 A. M., the on 17th. Feathers of the former were clinging to leaves above the nest and some were on the ground. Two notable changes were recorded in the behavior of the male. Frequency of singing increased and he flew beyond the confines of his territory. Wherever he went he always returned to the nest environs, but was never seen immediately at the nest. When in his feeding ground he flew so far beyond that his voice was barely audible. Previously, he had never fed south of the borderline 
of brush in which the nest was located. Now, he flew so far in that direction that he was out of hearing. He was gone 29 minutes, then returned to the nest vicinity, still singing. He seemed to be searching and calling in all directions for his mate and nestlings. There was no pause in his singing. $P a$ chibby chu he sang. The last syllable had an unmistakably plaintive quality. The 19th was the last day of observation. The bird was still flying far afield but never failed to return to his territory. His singing was constant, but subdued and colorless. When he flew east of the nest (a direction not included in his territory, except for a matter of a few feet), and continued so far that his voice became barely audible, I followed him and overtook him singing in a Miconia bush, a few feet from the trail that led back, past his nest, and there I left him.

More data is needed to determine the length of the incubating season and the time from the hatching of the young to their departure from the nest, also a more extended study of the nestlings and of other problems that arise in the mind of the observer that still remain unsolved. 


\section{Explanation of Plates}

Habitat of Latimer's Vireo (Vireo latimeri Baird)

Fig 1.-Nest in lower branches of tall tree on left; feeding ground on right of trail.

Fig. 2.-Feeding territory, overgrown with icaco brush.

Fig. 3.-Nest of Latimer's Vireo (Vireo latimeri Baird). Shows white spider sacs at base of nest.

Fig. 4.-Eggs of Latimer's Vireo (Vireo latimeri Baird). Laid April 8 and 9, an exceptionally early record. Nest deserted.

Fig. 5. Brooding bird.

Fig, 6.-Bird feeding young.

Fig. 7.-Nest of Latimer's Vireo (Vireo latimeri Baird). Excepitonal. Outer layer of gray lichen; no spider egg sacs or moss. Never occupied. 


\section{PLATE II}
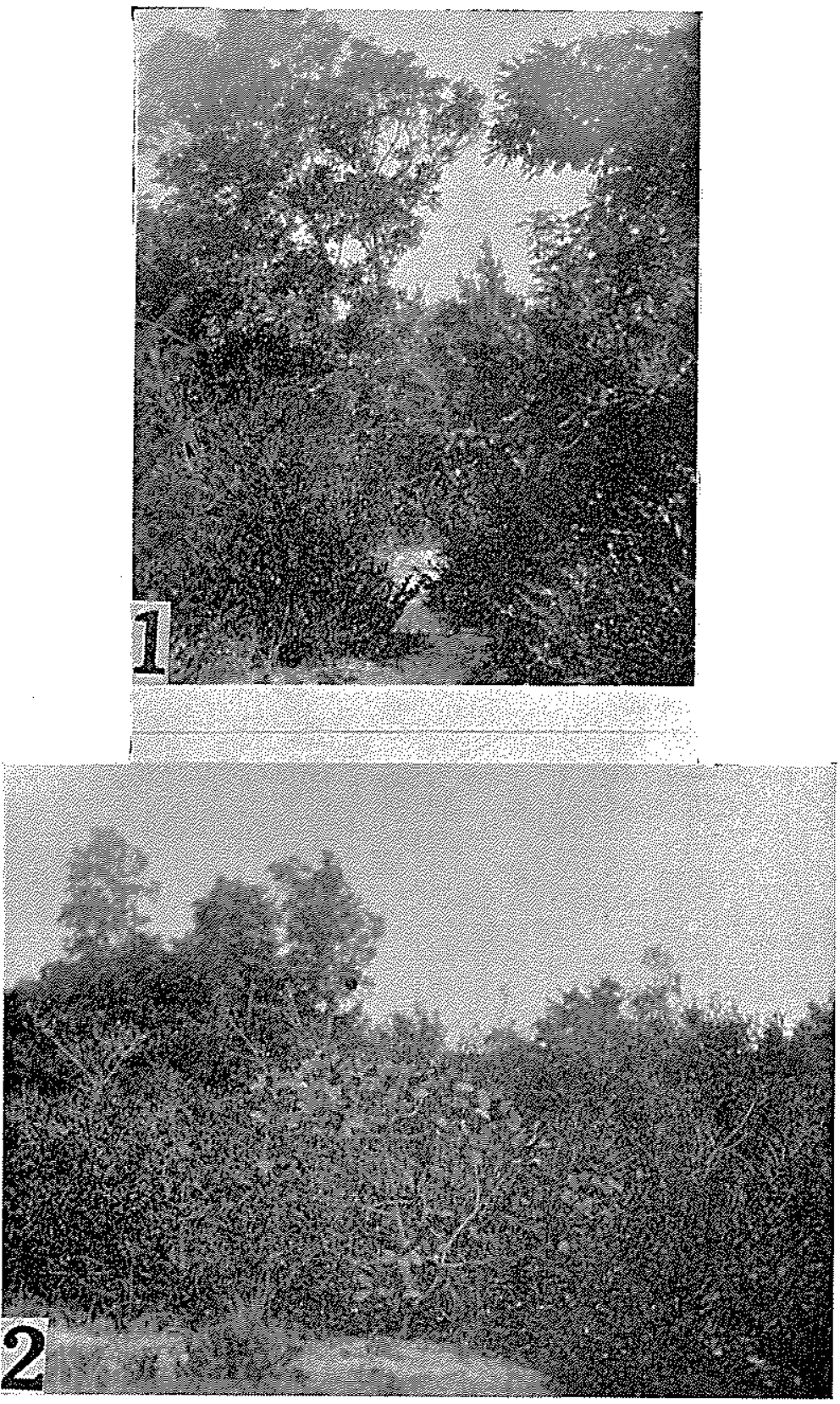

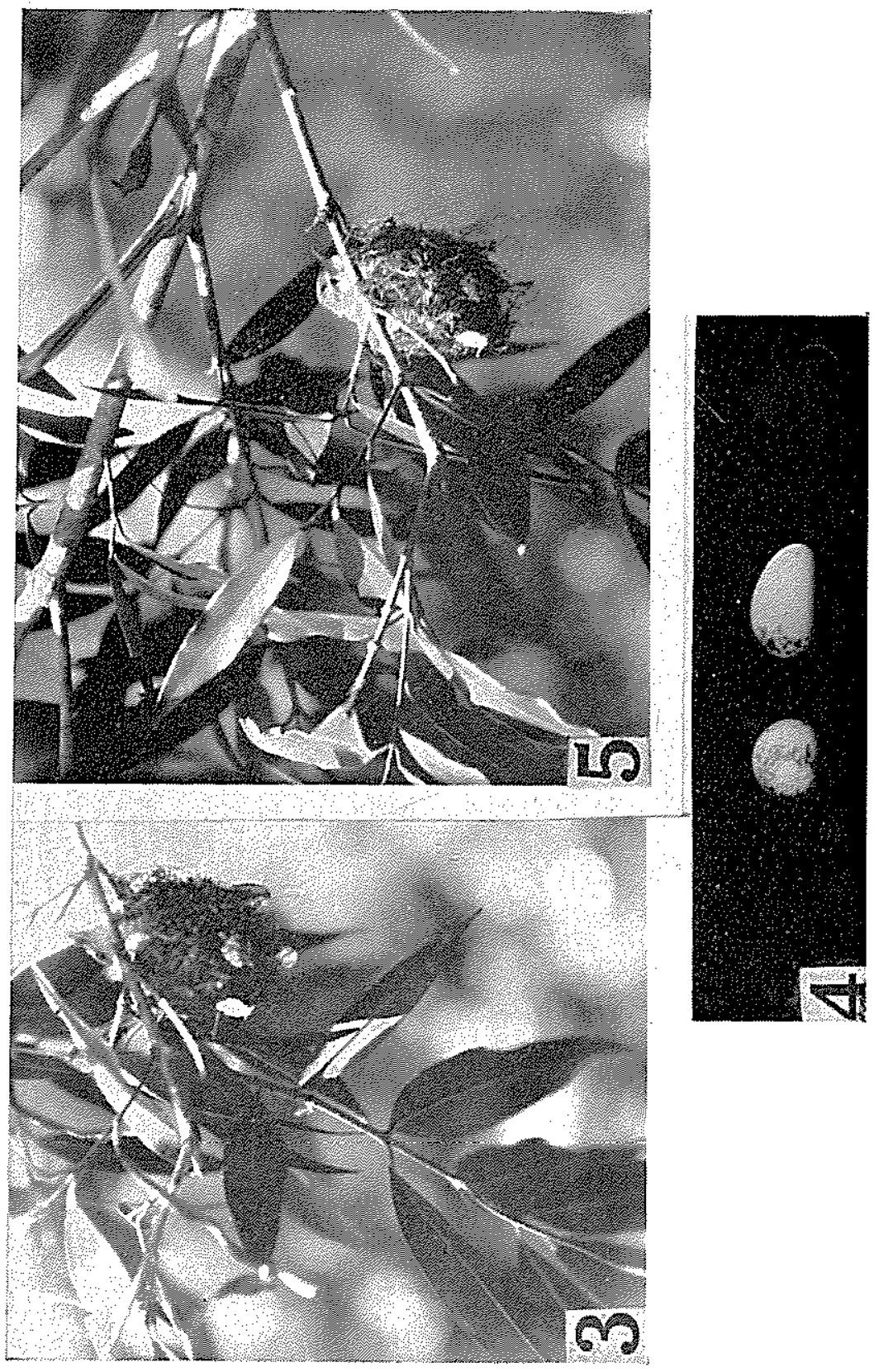

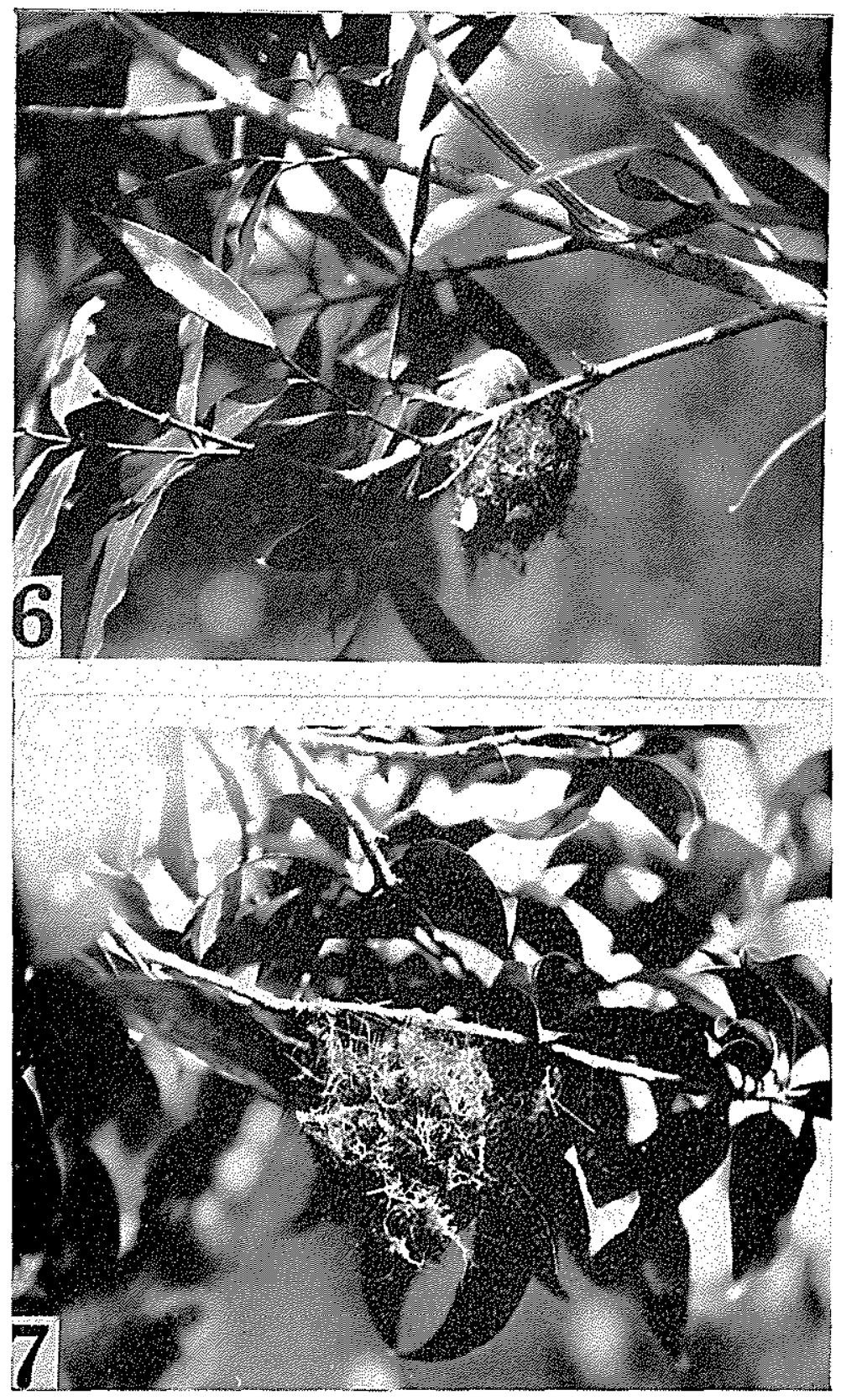